УДК 37.035 .7

DOI:

Борис Пантюхов, аспірант кафедри загальної педагогіки та дошкільної освіти Дрогобицького державного педагогічного університету імені Івана Франка

\title{
ВІЙСЬКОВЕ ВИХОВАННЯ В УМОВАХ СЬОГОДЕННЯ: ПРОБЛЕМИ І ПЕРСПЕКТИВИ
}

У статті проаналізовано стан сучасного військового виховання в Україні. Констатовано, щуо темпи і глибина здійснених перетворень у системі військової освіти, стан і якість підготовки військових фахівців не повною мірою задовольняють запити сектору безпеки й оборони. Наголошено на актуалізації питань військового виховання у сучасних умовах. Висвітлено здобутки та недоліки теорії і практики військового виховання в Україні. Доведено важливість військово-патріотичного виховання в системі військової освіти; названо можливі напрями його удосконалення.

Ключові слова: військове виховання; військова освіта; військово-патріотичне виховання; виховна робота; Збройні Сили Украӥни.

תim. 5.

Borys Pantyukhov, Postgraduate Student of the General Pedagogy and Preschool Education Department Drohobych Ivan Franko State Pedagogical University

\section{MILITARY EDUCATION UNDER PRESENT CONDITIONS: PROBLEMS AND PERSPECTIVES}

The article analyzes the state of modern military education in Ukraine. It is stated that the pace and depth of implemented reforms in the system of military education, as well as the state and quality of training of military specialists do not fully meet the demands of the security and defense sector. The issues of military education under present conditions are emphasized. On the basis of analysis of normative documents, the main directions of educational work in the Armed Forces are highlighted. They include the following: moral and psychological support of combat and mobilization preparedness of troops (forces), combat duty, combat service, operational and combat training, specific activity of military formations; moral and psychological support of military discipline and prevention of offenses; information advocacy; cultural and educational work; military and social work. The achievements and drawbacks of the theory and practice of military education in Ukraine are highlighted. The importance of patriotic education in the system of military education is proved. The emphasis is placed on the need of practical application of scientifically grounded approaches to methodological, organizational and legal principles and technologies of military and patriotic education, coordination of efforts and unity of views of the military command and control units of the Armed Forces of Ukraine with regard to military and patriotic education of personnel and the role of educational and socio-psychological institutions in this process, specification of the mechanism of implementation of military and patriotic education programs in the Armed Forces of Ukraine for corresponding periods, coordination of actions of state authorities, military management, military and patriotic public associations regarding the organization of military and patriotic education of citizens and purposeful preparation for military service. Through an analysis of normative documents, ways of improving educational work in the Armed Forces of Ukraine are defined: updating its content in accordance with the realities of the current situation in society, the state and the army, improving its organizational and methodical aspects, and introducing new flexible technologies into the educational process.

Keywords: military education; patriotic education; an educational work; Armed Forces of Ukraine.

П остановка проблеми. Екстремальні умови, в які потрапила Україна на сучасному етапі, виявляючи ознаки системної кризи в усіх галузях суспільнодержавної діяльності, стали водночас пусковим механізмом трансформації українського суспільства та радикальної перебудови всього сектору національної безпеки. Зумовивши колосальні людські, матеріальні, фінансові втрати, гібридна агресія проти нашої країни підняла хвилю патріотизму українців, прискорила формування й укріплення громадянського суспільства, яке відіграло вагому роль у протидії агресивним силам в усіх сферах. Завдяки мужності і відвазі пересічних громадян, героїзму добровольців, військовослужбовців, правоохоронців, єднанню всього українського народу у справі захисту Вітчизни вдалося зупинити подальшу експансію зовнішньої агресії. Втім, гібридна війна, розв'язана Російською Федерацією, триває. 3 огляду на це, першочерговим завданням держави $€$ створення принципово нової системи національної безпеки 
відповідно до наявних ресурсів і масштабів існуючих загроз. Важлива роль у цьому процесі належить удосконаленню професійної військової освіти як основного джерела забезпечення військово-оборонної галузі країни висококваліфікованими кадрами.

Аналіз останніх досліджень і публікацій. Проблематика підготовки військових кадрів протягом століть викликає значний інтерес дослідників, і як педагогічний феномен вивчається за різними напрямами. Будучи міждисциплінарною галуззю, вона стала предметом дослідження різних галузей науки - філософії, соціології, історії, педагогіки тощо.

Аналіз сучасного стану військового виховання досліджувався у працях А. Афанасьєва, В. Дзюби, Я. Зорія, М. Зубалія, Г. Коваля та ін. Науковці, зокрема, проаналізували сучасний стан виховання військовослужбовців Збройних Сил, обгрунтували зміст і розробили технології виховання майбутніх військових фахівців різних рівнів, відомств і видів військ Збройних Сил України в контексті специфіки їх професійної діяльності (офіцеріврезервістів, військовослужбовців-строковиків, прикордонників, правоохоронців та ін.).

Мета статті полягає в окресленні проблем та перспектив розвитку військового виховання в Україні в сучасних умовах.

Виклад основного матеріалу. За перші десятиліття незалежності України спільними зусиллями влади, науковців, освітян вдалося закласти міцне підгрунтя національної системи військової освіти, метою якої було визначено виховання нових генерацій військових фахівців як національно свідомих громадян, здатних на високому фаховому рівні виконувати завдання 3 оборони України, захисту її суверенітету, територіальної цілісності та недоторканності. Водночас вивчення особливостей становлення української системи військової освіти в перші десятиліття незалежності дає підстави стверджувати, що цей процес відбувається в умовах постійного перегляду підходів до забезпечення національної безпеки та оборони держави, принципів і напрямів підготовки усіх складових військово-оборонної галузі до захисту національних інтересів, мінливості стратегій розбудови української армії, а відтак не завжди $\epsilon$ конструктивним і результативним. Наслідком цього стало накопичення прогалин і проблем у системі професійної військової освіти, серед них: розбіжність цілей і змісту навчання військових фахівців із сучасними реаліями професійної військової діяльності, здобутками воєнної науки і військово-технічного поступу; невпорядкованість мережі вищих військових навчальних закладів, військових навчальних підрозділів закладів вищої освіти, спеціальних навчальних центрів тощо; невідповідність освітніх технологій вимогам формування професійної компетентності військового фахівця; застарілість матеріальнотехнічного забезпечення освітнього процесу у військових навчальних закладах; недосконалість нормативно-правової бази системи професійної військової освіти тощо. 3 метою усунення цих недоліків системи військової освіти було затверджено Замисел розвитку системи військової освіти на період до 2016 року (2011р.), а згодом і Програму реформування військової освіти на період до 2017 року (2013 р.), які визначили загальні підходи і конкретні заходи щодо приведення якісних, кількісних і вартісних показників системи військової освіти у відповідність до завдань, перспективної структури та чисельності Збройних Сил. Відтак протягом останніх років проводиться значна робота щодо реструктуризації системи військової освіти, оптимізації ії інституційної мережі, стандартизації процесу професійної підготовки військових фахівців, модернізації дидактичних засад освітньої діяльності військової школи тощо $[1 ; 5]$.

Втім критичне переосмислення перших результатів проведених реформ виявило, що темпи і глибина здійснених перетворень у системі військової освіти, стан і якість підготовки військових фахівців не повною мірою задовольняють запити сектору безпеки й оборони, Збройних Сил та інших військових формувань щодо кваліфікованого кадрового забезпечення, особливо в теперішніх умовах війни. Суттєва зміна структури сектору безпеки й оборони, завдань і функцій усіх його складових, збільшення штатної чисельності особового складу Збройних Сил та інших військових структур вимагає подальших трансформацій у системі військової освіти та організації підготовки військових фахівців. Сам факт гібридної зовнішньої агресії проти України зумовлює потребу в нових підходах до реформування військової освітньої системи, які б відповідали та сприяли реалізації нової державної політики в галузі безпеки і оборони, передбачали ефективне використання організаційних, інформаційних, технологічних, фінансових, матеріально-технічних та інших ресурсів, забезпечували підвищення якості підготовки військових кадрів, здатних належним чином виконувати свій громадянський і професійний обов'язок в умовах складної воєнно-політичної, оперативно-стратегічної ситуації, яка склалася внаслідок збройної агресії проти України. 
За час протистояння російській агресії отримано багато складних уроків та здобуто безцінний бойовий досвід, що, без сумніву, мають бути вивчені у стінах військових шкіл й стати основою системних перетворень у сфері військової освіти. Російсько-український конфлікт та його наслідки змушують по-новому осмислити методологічні, соціально-політичні, дидактичні, організаційні проблеми професійної підготовки військових фахівців. Сьогодні Україна перетворилася на полігон для випробування агресором ідей та принципів війни нового типу, яка вирізняється застосуванням некласичних засобів і нетрадиційних способів боротьби, що, своєю чергою, ставить перед системою військовопрофесійної освіти низку якісно нових проблем і питань щодо цілей, змісту, методів, організації тощо освітнього процесу. Тривалість і невизначеність періоду гібридної війни на сході України, урізноманітнення форм і методів ㄲï проведення у перспективі актуалізує проблеми підвищення рівня управління системою військової освіти, перегляду переліку військових спеціальностей від тактичного до оперативностратегічного рівнів, стандартизації військової освіти за усіма освітньо-кваліфікаційними рівнями й напрямами підготовки, технологізації та інформатизації освітнього процесу у військових школах тощо. Таким чином сучасний етап функціонування і реформування системи військової освіти передбачає розв'язання широкого комплексу складних управлінських, нормативно-правових, структурно-організаційних, теоретико-методологічних, фінансово-економічних, матеріально-технічних та інших завдань як передумови зростання військово-професійного, інтелектуального, духовно-морального потенціалу військових фахівців, зміцнення обороноздатності України та її Збройних Сил.

На тлі розв'язання сучасних проблем спостерігаємо й особливу актуалізацію питань військового виховання. Процес утвердження системи виховання українського війська започатковано прийняттям Концепції виховної роботи у Збройних Силах та інших військових формуваннях України (1998р.), що окреслює шляхи і засоби перебудови виховної діяльності у військових формуваннях на якісно нових засадах - державної і патріотичної спрямованості, поєднання національних, історичних та культурних традицій з почуттям нового, орієнтації на ідеали демократії та гуманізму, взаємозалежності змісту, форм і методів виховної роботи тощо. Основними напрямами виховної роботи в Збройних Силах документ визначає: морально-психологічне забезпечення бойової і мобілізаційної готовності військ (сил), бойового чергування, бойової служби, оперативної та бойової підготовки, специфічної діяльності військових формувань; морально-психологічне забезпечення військової дисципліни та профілактика правопорушень; інформаційно-пропагандистське забезпечення; культурно-виховну і просвітницьку роботу; військово-соціальну роботу[2]. Згодом ці ідеї були доповнені положеннями Концепції гуманітарного і соціального розвитку у Збройних Силах України (2004 р.), яка відображає науково обгрунтовану систему поглядів на поширення і закріплення демократичних, соціальних цінностей у військових формуваннях, гуманізацію всіх сфер військової діяльності, та Концепції ідеологічної роботи у Збройних Силах України (2013 р.), що визначає основні засади, принципи та порядок реалізації воєнно-ідеологічної роботи з метою формування у військовому середовищі системи світоглядних ідеалів, цінностей та орієнтирів в інтересах ефективного виконання завдань оборони України, захисту їі суверенітету, територіальної цілісності і недоторканності. Положення цих документів акумулюють в собі запити посилення усіх складових загальної системи виховання українського війська, надання виховному процесу ідейного підгрунтя, цільової спрямованості та методологічних орієнтирів [1; 4].

Отже, система виховної роботи в українській армії з перших років незалежності розбудовується на засадах української державницької ідеології, національних цінностей і пріоритетів, військових традицій українського народу, а також основних норм і принципів суспільної моралі з метою формування в особового складу Збройних Сил національної свідомості й культури, гуманістичного світогляду, високих моральнобойових якостей, морально-психологічної готовності до захисту Батьківщини. Положення військової етики, правові норми військової діяльності, ідеї зумовленості цілей і завдань виховання змістом військового обов'язку, конституційними і доктринальними вимогами до військової служби та згуртування особового складуукраїнських військових формувань навколо національних інтересів державної незалежності оформлюють концептуальний каркас системи військово-виховної роботи.

Однак не зважаючи на ці здобутки, теорія i практика військового виховання в Україні не позбавлена суперечностей і недоліків. Часом впадає у вічі їі безсистемність, стихійність, що виявляється у проведенні значної кількості розрізнених, методологічно непов'язаних виховних 
заходів, неузгодженість і нескоординованість функціональних обов'язків різних структур виховної роботи, наслідком чого є дублювання виховних дій і впливів, непослідовність планування, організації та управління процесом виховання військовослужбовців, що відображаються у суперечностях цільових, змістових, методичних, організаційних аспектів виховної роботи в Збройних Силах, звітно-показовий характер здійснення виховної діяльності, що відображається уїі здійсненні як формальної вимоги, без розуміння суті справи, а подекуди і всупереч їй. Усе це позбавляє виховний процес конструктивності, надає йому екстенсивного характеру.

Відтак попри належну розробку теоретичних, концепційних, методичних підвалин військового виховання в Україні нинішній стан справ в цій сфері залишається ще далеким від бажаного. Красномовним свідченням проблем стали передовсім події, пов'язані з анексією Російською Федерацією Криму, в ході яких велика кількість офіцерського корпусу Збройних Сил, починаючи 3 генералітету, перейшли на сторону ворога й лише близько третини українських військовослужбовців не зрадили присязі на вірність народу України. Спостерігалися й непоодинокі випадки дезертирства та інших злочинів у лавах Збройних Сил під час антитерористичної операції на сході України. Це ще раз підтвердило давню істину про те, що військова справа часом більше вольова, ніж розумова, навіть на тлі безпрецедентного військово-технічного прогресу, й, відповідно, змушує по-новому осмислити значення військового виховання, шукати нові підходи до організації виховної роботи в українській армії.

Сучасні реалії військово-політичного життя України значно ускладнили завдання військового виховання. В умовах нещодавніх революційних подій, порушення територіальної цілісності держави, зовнішньої збройної агресії по-новому осмислюються такі історично сформовані цінності, як “Батьківщина”, “Патріотизм”, “Честь”, "Гідність", “Самовідданість” та ін., внаслідок чого за останні роки і сама ідея формування і розвитку особистості громадянина, патріота, захисника Вітчизни зазнає суттєвих змін. Йдеться про визначення єства українського патріота не стільки за етнічними чи етнокультурними, скільки за ціннісними критеріями, серед яких незалежність і державний суверенітет України, європейські ідеали свободи, справедливості, принципи правової держави та народовладдя. Про це свідчать положення Концепції національно-патріотичного виховання дітей та молоді (2015 р.), Концепції військовопатріотичного виховання у Збройних Силах України (2010 р.), Концепції розвитку державнопатріотичних та військових традицій у Збройних Силах України (2013 р.) та ін.

Зміст згаданих концепцій розкривається шляхом викладу сукупності основних ідей, положень, що визначають спрямованість, характер та інші особливості військовопатріотичного виховання, готовності гідно служити Батьківщині у сучасних умовах. Їх структура охоплює теоретичні основи патріотичного виховання, конкретизовані цілі, уточнені завдання, сформульовані напрями діяльності та механізми їх реалізації. Впровадження їхніх положень передбачає, по-перше, застосування в практичній діяльності науково обгрунтованих підходів щодо методологічних, методичних, організаційних, правових засад i технологій військовопатріотичного виховання, його ролі і місця у Збройних Силах України 3 урахуванням національно-історичних і військових традицій українського народу, по-друге, координацію зусиль та єдність поглядів органів військового управління Збройних Сил України щодо військовопатріотичного виховання особового складу та визначення в цьомупроцесі ролі органів виховної та соціально-психологічної роботи, по-третє, конкретизацію механізму реалізації програм військово-патріотичного виховання у Збройних Силах України на відповідні періоди, по-четверте, узгодження дій органів державної влади, військового управління, військово-патріотичних громадських об'єднань щодо організації військово-патріотичного виховання громадян i цілеспрямованої підготовки їх до військової служби. Запропоновані нові концептуальні підходи до військово-патріотичного виховання грунтуються на його розумінні як процесу цілеспрямованого, систематичного, організованого та планомірного впливу на свідомість і поведінку особового складу військових формувань задля формування в нього патріотизму через виховання високих громадянських, моральних, психологічних, військово-професійних і фізичних якостей, необхідних для реалізації його інтелектуального та творчого потенціалу в інтересах всебічного розвитку суспільства і Збройних Сил України, а також забезпечення безумовної готовності до сумлінного виконання військового обов'язку та захисту Вітчизни.

Висновок. Отож, на сьогодні створені належні умови для реформування системи виховання військових кадрів, систематизовано концептуальні підходи до розв’язання цієї проблеми, визначено 
напрями діяльності, обгрунтовано принципи їі здійснення. Положення нових концепцій, програм, перспективних планів виховання українського війська актуалізують необхідність оновлення його змісту відповідно до реалій сучасної ситуації у суспільстві, державі, армії, вдосконалення його організаційно-методичних аспектів, впровадження у виховний процес нових більш гнучких технологій.

\section{ЛІТЕРАТУРА}

1. Замисел розвитку системи військової освіти на період до 2016 року: рішення Міністра оборони України від 18.06.2011 № 263/1/2157 [Електронний peсурс]. - Режим доступу: www.mil.gov.ua/

2. Концепція виховної роботи уЗбройних Силах та інших військових формуваннях України // Флот України. - 1998. - 19 вересня. - С. 52-55.

3. Концепція гуманітарного і соціального розвитку у Збройних Силах України // Народна армія. - 2004. - 4 лютого. - С. 1-5.

4. Наказ Міністерства оборони від 05 лютого 2013 року № 78 “Про затвердження Концепції ідеологічної роботи у Збройних Силах України” [Електронний ресурс]. - Режим доступу: http:// www.mil.gov.ua/ministry/normativno-pravova-baza/ nakazi-ministra-oboroni-ukraini/nakazi-ministerstvaoboroni-ukraini-za-2013-rik.html/

5. Програма реформування військової освіти на період до 2017 року (погоджена Міністром освіти та науки України та затверджена Міністром оборони України 28.03.2013 р.) [Електронний pecypc]. - Режим доступу: www.mil.gov.ua/ index.php?past=educational/

\section{REFERENCES}

1. Zamysel rozvytku systemy vijskovoyi osvity na period do 2016 roku: rishennya Ministra oborony Ukrayiny vid 18.06.2011 № 263/1/2157 [Design for the development of the military education system for the period until 2016: the decision of the Minister of Defense of Ukraine dated June 18, 2011 No. 263/1/ 2157]. Available at: www.mil.gov.ua/ [in Ukrainian].

2. Koncepciya vykhovnoyi roboty u Zbrojnykh Sylakh ta inshykh vijskovykh formuvannyakh Ukrayiny (1998). [Concept of educational work in the Armed Forces and other military formations of Ukraine]. Fleet of Ukraine. September $19^{\text {th }}$, pp. 5255. [in Ukrainian].

3. Koncepciya gumanitarnogo i socialnogo rozvytku u Zbrojnykh Sylax Ukrayiny (2004). [The Concept of Humanitarian and Social Development in the Armed Forces of Ukraine]. People's Army, February $4^{\text {th }}$, pp. 1-5. [in Ukrainian].

4. Nakaz Ministerstva oborony vid 05 lyutogo 2013 roku №78 "Pro zatverdzhennya Koncepciyi ideologichnoyi roboty u Zbrojnykh Sylakh Ukrayiny" [Order of the Ministry of Defense of February 5, 2013 No. 78 "On Approval of the Concept of Ideological Work in the Armed Forces of Ukraine"]. Available at: http://www.mil.gov.ua/ministry/ normativno-pravova-baza/nakazi-ministra-oboroniukraini/nakazi-ministerstva-oboroni-ukraini-za-2013rik.html/ [in Ukrainian].

5. Prohrama reformuvannya vijskovoyi osvity na period do 2017 roku (pogodzhena Ministrom osvity ta nauky Ukrayiny ta zatverdzhena Ministrom oborony Ukrayiny 28.03.2013 r.) [Military Education Reform Program for the period up to 2017 (coordinated by the Minister of Education and Science of Ukraine and approved by the Minister of Defense of Ukraine on March 28, 2013)]. Available at: www.mil.gov.ua/ index.php?past=educational/ [in Ukrainian].

Стаття надійшла до редакції 16.11.2018

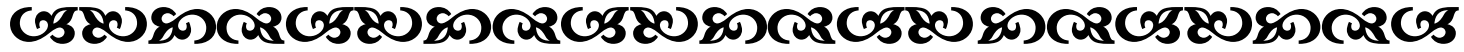

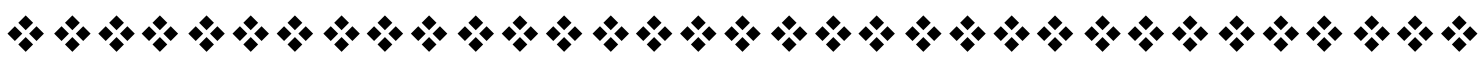 \\ "Видатні особистості бормуються не за допомогою красивих промов, а власною працею і його результатами". \\ Aльберт Ейнштейн \\ один з найвизначніших ббізиқів ХХ століття}

"Ефективність навчання, його гуманістична сутність зумовлюються в периу чергу професіоналізмом і висоқою технологічною қультурою педагога".

Василь Сухомлинський український педагог, публіиист

\section{$\% * \% * \%$

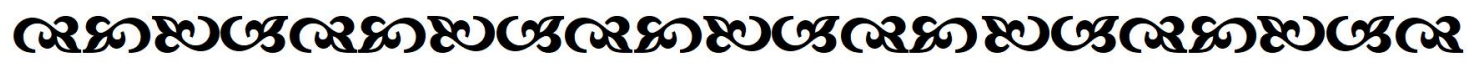

